\title{
Transition to a New Economy: Transformation Trends in the Fields of Income and Salary Functions
}

\author{
Olena Grishnova ${ }^{1}$, Andriy Cherkasov $^{2}$, Olena Brintseva ${ }^{3 *}$, Olena Sakovska ${ }^{4}$, Anatoly \\ Ostapchuk $^{5}$ \\ ${ }^{1}$ Taras Shevchenko National University of Kyiv, Ukraine \\ ${ }^{2}$ Institute of Personnel Training at the State of Employment Service, Ukraine \\ ${ }^{3}$ State Higher Educational Institution "Kyiv National Economic University named after Vadim \\ Getman", Ukraine \\ ${ }^{4}$ Uman National University of Horticulture, Ukraine \\ ${ }^{5}$ National University of Life and Environmental Science, Ukraine
}

\begin{abstract}
The rapid spread of information technologies and other phenomena in the new economy causes significant changes in the social and employment spheres. The objective is mainly to analyze and systematize the peculiarities of labor and payment for it in the new economy. In this paper are used the analytical grouping method for characterizing salary functions, as well as changes in the social and labour sphere that take place in the new economy, correlation-regression analysis to determine the relationship between average income and factors affecting its level. The results of the paper show three important findings. Firstly, the gradual changes in the content of labour and forms of its organization that happen in modern conditions under the influence of dissemination of information and communication technologies require new approaches to income adjustment. Secondly, the authors also found that the fair employee compensation, ensuring productive employment in modern conditions, is a challenge not only of the national but also of international scale. Thirdly, the prospective directions of reducing inequality and social tension in society is the guarantee of the basic unconditional income; progressive tax on all types of income; reduction of the length of working time while maintaining payments and improving productivity.
\end{abstract}

\section{INTRODUCTION}

The rapid dissemination of information technologies and other phenomena in the new economy causes significant changes in the social and employment spheres. The noted events are primarily related to the changes in the content of work and forms of its organization, the emergence of new professions, in particular in the IT field, extensive development of high-

* Corresponding author: nadya-reznik@ukr.net 
technology sectors of the economy, the expansion of opportunities for the formation and use of human capital, an increase in the options of human choice, but also the emergence of new risks. Gradual changes in the content of work and its organization forms also result in the transformation of the integrity and functions of remuneration. New criteria for assessing the personal labour input of employees lead to changes in compensation, forming different, rather diversified sources of income. A modern employee with the help of information and communication technologies can simultaneously participate in many projects. In the new economy, the diversity and flexibility of the employment conditions increases, an employee can enter into individual contracts. Furthermore, in the new conditions, the employee has the highest degree of freedom and independence, professional networks of specialists and freelances are becoming widespread, and the decentralization of business processes and management increases. However, changes in the social and employment sector, inherent in a new economy, can also result in a decrease of employment stability, less social guarantees for employees, an increase in the inequality of compensations and incomes in general.

During the $20^{\text {th }}$ century, work from hard duty to satisfy the needs of survival gradually turned into a way of development and self-actualization. It happened for the following reasons: the majority of the population was engaged in hired labour; work and profession became the axis of human existence, determining the position in a society, income, lifestyle, social circle, etc.; the changes lead to the formation of a special employment democracy, employment values; people started to view employment as a source of property and well-being, it became the centre of economic progress.

At the same time, tireless work and its ever-increasing productivity leads to a steady decline in demand for human resources. Fewer people can produce more and more goods and services (just in the past 150 years, labour productivity has grown more than 50 times). Due to the automation of production and the development of robotics, deserted manufacturing sites are no longer surprising. According to forecasts, in the next decades, there will be an ongoing decline in manufacturing employment and it will approach the mark of 2-3\%. The emergence of each new, more efficient workplace destroys dozens and hundreds of old ones. Therefore, modern economic growth, based on scientific and technological progress, is "growth without jobs." The overall objective of the paper is to analyze and systematize the peculiarities of labor and payment for it in the new economy, to investigate the gradual transformation of its functions, to identify the trends in changes of incomes of the population under the influence of the computerization of human life, and to substantiate the directions of agents' adaptation to these changes at different levels.

\section{PRESENTATION OF THE MAIN MATERIAL}

\section{Salary and Wage Functions in Traditional and New Economy}

At the same time, we cannot argue that, in modern conditions, there are revolutionary changes in the social and employment sphere. These, albeit very deep transformations that take place are, rather, evolutionary, as they are a natural consequence of social development technological, economic, social progress, which has acquired special, inherent features with the advent of computer and the development of global Internet.

Considering the transformation of the classical functions of salaries and wages in the context of the transition to a new economy, it is necessary to distinguish the following distinctive features. Thus, society increasingly expects business to fulfill the principle of social responsibility and participation in solving important social issues. It is this principle that should become the basis for the image and mission of the company. $77 \%$ of the interviewed respondents called social responsibility an important or very important business component. Despite the connection between the social impact and financial performance of the company, only $18 \%$ of respondents regard social responsibility as the main priority of the corporate 
strategy. $34 \%$ of companies do not have enough social programs or such program's lack financing, and $22 \%$ do not pay attention to it at all.

\section{Transformation Trends in the Field of Income and Salary in the Transition to a New Economy in the EU Member States and Ukraine}

In order to identify and assess the transformation trends in the field of incomes and employee compensation in the transition to a new economy, we examined the interconnections and dynamics of the average income and the main factors influencing it (working time, average duration of training and social transfers), in the EU member states and in Ukraine. The distribution of annual income in the Eurozone is rather uneven: so the income in the "richest" and "poorest" countries can vary 10-20 times. In Ukraine, we determined this indicator, taking into account the average annual euro rate for the relevant year; the rapid drop in the course of the national currency in crisis years had a negative effect on the dynamics of average annual incomes.

Table 1. Change of Average Income in EU Member States and Ukraine in 2008-2016, Euro per year.

\begin{tabular}{|c|c|c|c|c|c|c|c|c|c|}
\hline \multirow{2}{*}{ Country } & \multicolumn{9}{|c|}{ Year } \\
\hline & 2008 & 2009 & 2010 & 2011 & 2012 & 2013 & 2014 & 2015 & 2016 \\
\hline Belgium & 17,985 & 19,313 & 19,464 & 20,008 & 20,280 & 21,483 & 21,705 & 21,654 & 22,295 \\
\hline Bulgaria & 2,171 & 2,828 & 3,017 & 2,914 & 2,860 & 2,924 & 3,311 & 3,332 & 3,151 \\
\hline $\begin{array}{l}\text { Czech } \\
\text { Republic }\end{array}$ & 6,068 & 7,295 & 7,058 & 7,451 & 7,791 & 7,694 & 7,622 & 7,423 & 7,838 \\
\hline Denmark & 24,161 & 25,029 & 25,668 & 26,944 & 27,184 & 27,444 & 27,861 & 28,364 & 28,665 \\
\hline Germany & 18,309 & 18,586 & 18,797 & 19,043 & 19,595 & 19,582 & 19,733 & 20,668 & 21,275 \\
\hline Estonia & 5,547 & 6,209 & 5,727 & 5,598 & 5,987 & 6,579 & 7,217 & 7,889 & 8,645 \\
\hline Ireland & 22,995 & 22,445 & 20,512 & 19,726 & 19,748 & 19,856 & 20,169 & 21,688 & 22,407 \\
\hline Greece & 10,800 & 11,496 & 11,963 & 10,985 & 9,513 & 8,371 & 7,680 & 7,520 & 7,500 \\
\hline Spain & 13,966 & 14,795 & 14,605 & 13,929 & 13,868 & 13,524 & 13,269 & 13,352 & 13,681 \\
\hline France & 18,899 & 19,644 & 19,960 & 19,995 & 20,603 & 20,924 & 21,199 & 21,415 & 21,713 \\
\hline Croatia & : & : & 5,810 & 5,579 & 5,377 & 5,078 & 5,225 & 5,453 & 5,726 \\
\hline Italy & 15,640 & 15,605 & 15,964 & 15,971 & 15,979 & 15,733 & 15,759 & 15,846 & 16,247 \\
\hline Cyprus & 16,024 & 16,451 & 16,180 & 16,990 & 16,927 & 15,873 & 14,400 & 13,793 & 14,020 \\
\hline Latvia & 4,740 & 5,355 & 4,488 & 4,195 & 4,450 & 4,666 & 5,203 & 5,828 & 6,365 \\
\hline Lithuania & 4,111 & 4,715 & 4,030 & 3,857 & 4,337 & 4,698 & 4,823 & 5,180 & 5,645 \\
\hline Luxembourg & 30,917 & 31,764 & 32,333 & 32,538 & 32,779 & 33,301 & 34,320 & 35,270 & 33,818 \\
\hline Hungary & 4,400 & 4,739 & 4,241 & 4,493 & 4,696 & 4,449 & 4,512 & 4,556 & 4,768 \\
\hline Malta & 10,009 & 10,503 & 10,435 & 10,862 & 11,449 & 12,093 & 12,787 & 13,493 & 13,572 \\
\hline Netherlands & 19,522 & 20,156 & 20,292 & 20,310 & 20,562 & 20,839 & 20,891 & 21,292 & 22,733 \\
\hline Austria & 19,413 & 20,469 & 21,058 & 21,463 & 21,807 & 22,073 & 23,211 & 23,260 & 23,694 \\
\hline Poland & 4,155 & 5,097 & 4,405 & 5,025 & 5,060 & 5,164 & 5,336 & 5,556 & 5,884 \\
\hline Portugal & 8,143 & 8,282 & 8,678 & 8,410 & 8,323 & 8,177 & 8,229 & 8,435 & 8,782 \\
\hline Romania & 1,952 & 2,172 & 2,036 & 2,091 & 2,049 & 2,016 & 2,155 & 2,315 & 2,448 \\
\hline
\end{tabular}




\begin{tabular}{|l|c|c|c|c|c|c|c|c|c|} 
Slovenia & 10,893 & 11,864 & 11,736 & 11,999 & 12,122 & 11,852 & 11,909 & 12,332 & 12,327 \\
\hline Slovakia & 4,792 & 5,671 & 6,117 & 6,306 & 6,927 & 6,737 & 6,809 & 6,930 & 6,951 \\
\hline Finland & 19,794 & 20,962 & 21,349 & 21,826 & 22,699 & 23,272 & 23,702 & 23,763 & 23,650 \\
\hline Sweden & 20,217 & 20,477 & 18,897 & 21,584 & 23,852 & 25,401 & 25,838 & 25,306 & 25,164 \\
\hline UK & 18,923 & 16,262 & 17,106 & 17,136 & 19,166 & 18,694 & 20,528 & 21,028 & 21,136 \\
\hline Iceland & 32,206 & 22,362 & 18,320 & 18,973 & 19,361 & 21,234 & 22,487 & 24,554 & 28,379 \\
\hline Norway & 31,798 & 33,737 & 32,399 & 36,453 & 40,106 & 42,909 & 43,775 & 41,483 & 39,573 \\
\hline Switzerland & 26,987 & 28,958 & 30,666 & 33,936 & 39,407 & 40,791 & 38,162 & 39,586 & 44,253 \\
\hline Turkey & 2,903 & 3,049 & 2,754 & 3,326 & 3,222 & 3,438 & 3,497 & 3,386 & $:$ \\
\hline Ukraine & 2,374 & 1,797 & 2,284 & 2,474 & 3,123 & 3,217 & 2,134 & 1,675 & 1,651
\end{tabular}

Source: Calculated and formulated by the authors basing on Eurostat (2018), State Statistics Service of Ukraine (2018), National Bank of Ukraine (2018).

The variation in the hours worked per week of full-time employment is significantly lower than among EU member states, but its dynamics in 2008-2016 indicates a gradual decrease in the number of hours worked against the rising incomes. The average length of training varies considerably more: from 10.9 years in Italy to 19.0 years in Iceland in 2016.

We determined the strength of a relationship between the average income and the factors affecting it in the EU and Ukraine on the basis of a correlation-regression analysis.

Table 2. Relationship between Average Income and the Factors Affecting It in Individual EU Member States and Ukraine.

\begin{tabular}{|l|c|c|c|}
\hline Country & $\begin{array}{c}\text { Hours Worked per } \\
\text { Week of Full-Time } \\
\text { Employment }\end{array}$ & $\begin{array}{c}\text { Average } \\
\text { Length of } \\
\text { Training }\end{array}$ & $\begin{array}{c}\text { Social } \\
\text { Transfers }\end{array}$ \\
\hline Belgium & 0.804 & 0.948 & 0.888 \\
\hline Bulgaria & -0.762 & 0.817 & 0.608 \\
\hline Czech Republic & -0.775 & -0.814 & 0.561 \\
\hline Denmark & 0.134 & -0.050 & -0.370 \\
\hline Germany & -0.808 & 0.868 & 0.594 \\
\hline Estonia & -0.807 & 0.588 & -0.538 \\
\hline Ireland & 0.100 & -0.664 & -0.589 \\
\hline Greece & -0.876 & -0.824 & -0.654 \\
\hline Spain & 0.421 & -0.782 & -0.722 \\
\hline France & -0.806 & 0.965 & 0.849 \\
\hline Croatia & 0.383 & -0.455 & -0.075 \\
\hline Italy & -0.407 & 0.392 & 0.612 \\
\hline Cyprus & -0.511 & -0.537 & -0.555 \\
\hline Latvia & -0.068 & -0.253 & -0.195 \\
\hline Lithuania & -0.261 & 0.733 & -0.783 \\
\hline Luxembourg & 0.623 & 0.718 & 0.681 \\
\hline Hungary & 0.017 & -0.040 & -0.253 \\
\hline Malta & 0.258 & 0.191 & 0.498 \\
\hline Netherlands & 0.205 & 0.637 & 0.536 \\
\hline Austria & -0.984 & 0.925 & 0.922 \\
\hline Portugal & -0.280 & 0.115 & 0.279 \\
\hline
\end{tabular}




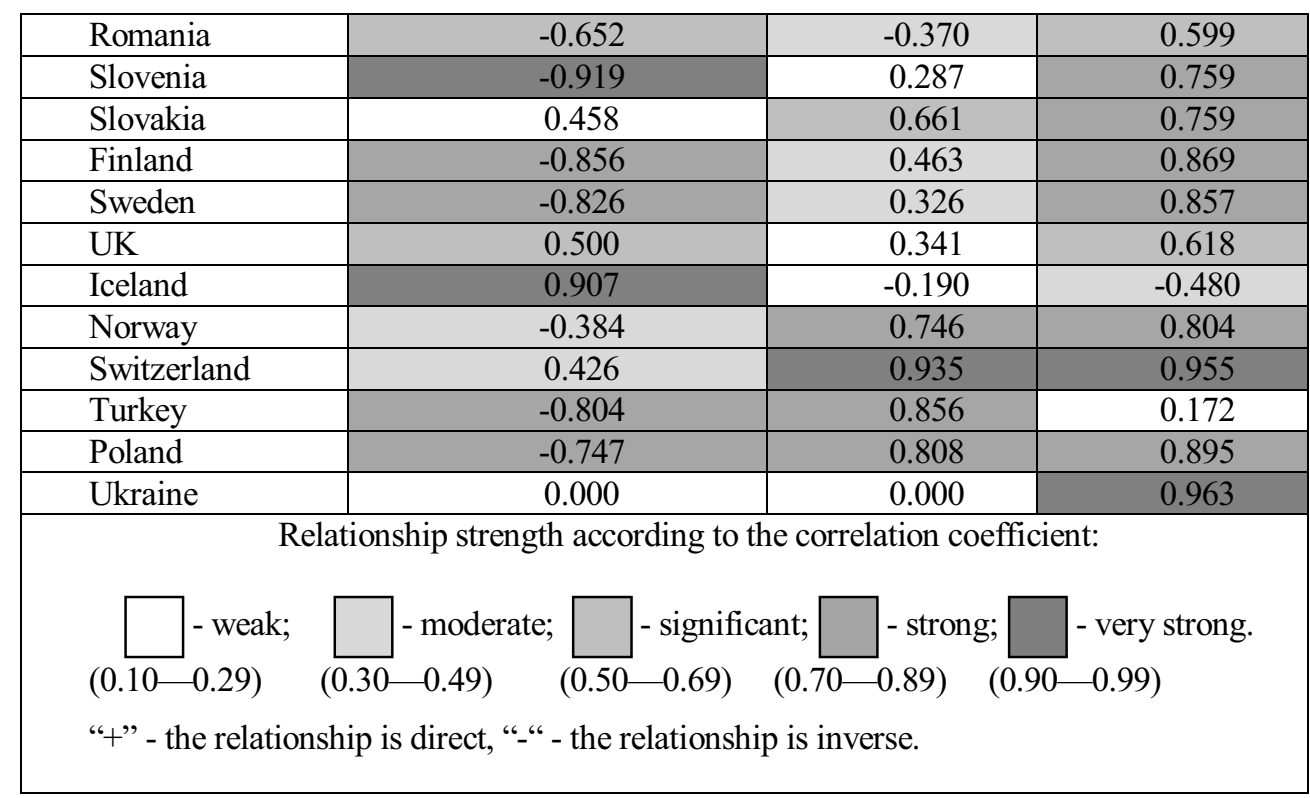

Source: Calculated by the authors according to the data in Eurostat (2018), State Statistics Service of Ukraine (2017, 2018), United Nations Development Program (2018), National Bank of Ukraine (2018).

The results of the conducted analysis are the most important part; they indicate that under present conditions, the cumulative income does not depend on the time spent at the primary place of employment. Wages, salaries and traditional employment gradually lose their fundamental importance in the life of a modern person in the era of digital technology. The income sources are gradually being diversified. The paper revealed a rather interesting trend: the increase in the length of training in the system of classical formal education no longer guarantees high incomes throughout life (in some countries within the study, the relationship between the length of training and income is even inverse). We observed the strongest impact of social transfers on incomes of the population in Ukraine, Switzerland, Austria, Belgium, Finland and France.

\section{CONCLUSIONS}

In the paper, we obtained empirical results that confirm the abovementioned theoretical hypotheses about the dynamic changes in the social and employment sphere and society in general; and the world community as a whole, the public administration of each individual country and every real or potential employee in particular have to prepare for it carefully. The changes in the social and employment sphere, associated with the spread of processes and phenomena, briefly summarized by the phrase "new economy", require in-depth research from the side of science, as well as increased attention from the managers at all levels - from personal to global one.

The social and employment sphere undergo the following major changes:

$\checkmark \quad$ Rapid growth of productivity;

$\checkmark \quad$ A rapid change in the labour market demand with its general decline;

$\checkmark \quad$ Change in the forms and systems of labour organization towards increasing flexibility and instability; 
$\checkmark$ Corresponding change in the main functions and forms of remuneration towards individualization, contract basis, dependence on the outcome;

$\checkmark \quad$ Transformation of the value system of modern employees and the loss of salary's positions as the foremost motivator of hired employment;

$\checkmark$ Differentiation of the income system, increasing the role of social transfers in the absence of jobs;

$\checkmark$ Changing requirements for vocational education in terms of its specialization, intensification, accessibility and mobility as the main social elevator in an era of change;

$\checkmark \quad$ Further globalization and increasingly active redistribution of all resources around the world, including intellectual human capital.

Such radical transformations affect the lives of each person, opening up new opportunities and, at the same time, putting forward new threats. The global community as a whole, every single society, state, enterprise, every person must prepare themselves for such changes, because they simply cannot avoid them.

The study revealed a significant transformation of all wage functions in the transition to a new economy.

In such conditions, fair employee compensation and ensuring productive employment is a challenge not only of the national but also of international scale. Prospective directions of reducing inequality and social tension in society is the guarantee of the basic unconditional income; progressive tax on all types of income; reduction of the length of working time while maintaining payments and improving productivity. In addition to avoiding social dangers, it would be a proactive progressive function of expanding human development opportunities.

\section{REFERENCES}

1. O.G. Brintseva. Transformation of human capital in the context of changing the content of labour in the new economy. (Ukraine: aspects of labour, 3-4, 46-49, 2016)

2. Deloitte. Human capital trends, https://hctrendsapp.deloitte.com/reports/2018/newrewards.html (2018)

3. V. Dumanska. Remuneration of labor: Ukrainian problems against the background of world trends. (Ukraine: Aspects of Labor, 2, 35-40, 2015)

4. Eurostat. Hours worked per week of full-time employment, $\mathrm{http}: / /$ ec.europa.eu/eurostat $/ \mathrm{tgm} / \mathrm{table} . \mathrm{do} ? \mathrm{tab}=$ table $\&$ init $=1 \&$ language $=$ en $\& p \operatorname{code}=\operatorname{tps} 000$ 71\&plugin=1 (2018)

5. Eurostat. Mean and median income before social transfers (pensions included in social transfers) by household type, http://appsso.eurostat.ec.europa.eu/nui/show.do?dataset=ilc_di13b\&lang=en (2018)

6. Eurostat. Mean and median income by age and sex - EU-SILC survey [ilc_di03], http://appsso.eurostat.ec.europa.eu/nui/show.do?dataset=ilc_di03\&lang=en (2018)

7. M. Graham, V. Lehdonvirta, A. Wood, H. Barnard, I. Hjorth, D. P. Simon. The Risks and Rewards of Online Gig Work At The Global Margins. (Oxford: Oxford Internet Institute, 2017)

8. A. M. Kolot. Global social inequality of incomes: nature, trends, consequences. Social-Labour Relations: Theory and Practice, 2, 8-47 (2017)

9. State Statistics Service of Ukraine. Statistical Yearbook of Ukraine for 2016, (Edited by Werner I.E., Kyiv, 2017)

10. State Statistics Service of Ukraine. People. Official web-site. http://www.ukrstat.gov.ua/operativ/operativ2007/ds/nas_rik/nas_u/nas rik_u.html (2018)

11. The Future of Jobs Report. Insight Report. World Economic Forum, http://www3.weforum.org/docs/WEF_Future_of_Jobs_2018.pdf (2018) 